\title{
Analysis of Self and Peer Evaluation in Basic Volleyball Skills of Physical Education Teacher Candidates
}

\author{
Mümine Soytürk ${ }^{1}$ \\ ${ }^{1}$ Department of Physical Education and Sports Teaching, Manisa Celal Bayar University, Manisa, Turkey \\ Correspondence: Mümine Soytürk, Department of Physical Education and Sports Teaching, Manisa Celal Bayar \\ University, Manisa, Turkey. E-mail: soyturkmumine@gmail.com
}

Received: February 27, 2019

Accepted: March 17, 2019 Online Published: March 19, 2019

doi:10.5539/jel.v8n2p256

URL: https://doi.org/10.5539/jel.v8n2p256

\begin{abstract}
It might be of vital importance that teachers, who are the backbones of education system, should obtain their skills related to educating students who are in harmony with modern life in their process as teacher candidates. Physical education teachers should obtain features of quality teaching and using alternative methods of measurement during their bachelor's degree education. Thus, the aim of this study is to analyze efficiency of teacher candidates in movement analysis, self-evaluation and peer evaluation for four basic volleyball skills (forearm pass, setting, underhand serve and overhand serve). In the process of obtaining data, four observation forms were used. In the evaluation of forearm passing and overhand serve, observation forms developed by Ghorbanzadeh Koshki (2013) were used as evaluation tools. For overhand pass and underhand serve, observation forms developed by the researcher and experts were used. Also, information related to genders and ages of the teacher candidates was recorded. In the analysis of the data, $t$ test, Pearson correlation and partial correlation tests were used. In the reliability analyses, interclass correlation coefficient (ICC) and Cronbach Alpha analyses were used. As a result, the teacher candidates' scores for self-evaluation of their skills and their peers' scores were found to be correlated. No significant difference was found between the two evaluations. The findings were discussed in the frame of the importance for physical education teacher candidates to learn to analyze moves and to use alternative measurement techniques.
\end{abstract}

Keywords: volleyball, self-evaluation, peer evaluation, teacher candidate, physical education

\section{Introduction}

According to Özden (as cited in Çelikten, Şanal, \& Yeni, 2005), teachers are the basis of the education system (Göçer, 2016), and they are the enforcers of the education process. A teacher, according to the dictionary meaning, is the "a person whose profession is to teach information, teacher, master, mistress" (Turkish Language Institution, 2019). A teacher is also an educator, and, therefore, he/she needs to have serious knowledge of pedagogical formation. In addition to common teaching knowledge, teachers obtain the knowledge and teaching skills which are specific to the field in their teacher candidate education. Physical education and sports teaching, which, put simply, makes skill learning and teaching necessary together, includes the ability to teach the skills gained during the candidacy period while actively teaching. Physical education teacher candidates have to learn technical and tactical features of many individual and team sports and to use these as professional skills. There are many distinctions in sport skills. In the context of a variety of sports and games, the skills that include different behaviors such as hitting, kicking and catching stand out as discrete skills. Serial skills are a combination of many elements - and their following each other up such as in a series of gymnastic moves. The third type is continuous skills, such as swimming, running and cycling (Schmidt \& Wrisberg, 2000, pp. 5-6). A branch of sports can include one or more of the categories in this classification. Another distinction of motor skill application is made according to the transformation situation in the movement. One type of this is cyclic (rotation) movements, consisting of continuous repetitive movement sections such as running, cycling etc; on the other hand, the other type is acyclic (non-rotating movements) - often consisting of combinations of closed motion sections such as high jump, hammer throwing, and racquet games, and there might not be repetition at the same degree (Sayın, 2011, p. 36). In this sense, a physical education teacher candidate should develop the ability to know and teach the structure of movement which is specific to many sports branches. This requirement of his/hers needs to be supported by the knowledge of motion analysis specific to various branches. Learning the movement analysis is 
expected to help the trainee to present the arrangements and feedback (Mosston \& Ashworth, 2008) to be made to the student appropriately during the teaching process. Today, the use of easily accessible technology in the teaching of this, such as video shooting, can be used as an effective aid in evaluating both him/herself and another person. In our country, as of the 2005-2006 academic year, the student has been taken to the center along with the structuring approach. In addition, students' performance and skills assessment, and assessment and evaluation have gained a student-centered structure (Kösterelioğlu \& Çelen, 2016). This has increased interest in active learning and alternative assessment applications (Yurdabakan, 2012). In this journey towards learning by doing, a student can become conscious of performance by evaluating how much he/she has learnt and how much someone else has learnt objectively. Measurement is the prerequisite of evaluation (Yaşar, 2014b, p. 5). Evaluation involves the process of interpreting the measurement results by comparison with a criterion (Güler, 2015, p. 12) and consists of two elements; these are the measurement results and the criterion (Yaşar, 2014a). Measurements made in physical education and sports are in harmony with the general measurement definitions and contents (Kasap, Kemertaş, \& Sibel, 2018). It can be said that the most frequently used forms of evaluation are self-assessment and peer assessment. It can also be said that self-evaluation is a sort of self-conscious mirror. Anderson and Krathwohl (as cited in Yurdabakan, 2011) argue that an individual's judging of his/her ability to succeed means judging his/her own knowledge; Shrauger and Osberg (as cited in Yurdabakan, 2011) suggest that the individual will have done self-evaluation by this way. In this case, self-assessment is closely related to the phenomenon of metacognitive information. Peer evaluation can be seen as a mirroring of the individual who is learning through the performance of another. The evaluation process using both techniques logically necessitates critical thinking. Self and peer evaluation studies with teacher candidates in different fields can be found in the literature. The spatial ability self-evaluation competencies of mathematics teacher candidates were measured (Yllmaz, 2017). Self and peer evaluations of Turkish teacher candidates who took the Special Teaching Methods I course were taken (Göçer, 2016). It was found that pre-service teachers had a positive attitude towards using the self-assessment method after the application (Kösterelioğlu \& Çelen, 2016). The self-assessment of post-graduate students regarding their own qualifications was examined with a descriptive approach (Sezgin, Kavgaci, \& Kilinc, 2011). In the same way, a peer evaluation of formative academic writing among graduate students was examined (Topping, Smith, Swanson, \& Elliot, 2000). In an applied study that investigated the effect of joint and peer evaluation training on self-assessment skills of teacher candidates, it was revealed that peer evaluation was a good predictor of self-evaluation in the experimental group (Yurdabakan, 2012). In a peer teaching study conducted with English teacher candidates, self and peer evaluation were also carried out by using observation and interview techniques. Students suggested that this process developed their own teaching techniques and evaluation skills (Kavanoz \& Yüksel, 2010). The peer evaluation technique was used in the teaching of computer use by classroom teacher candidates (Gömleksiz \& Koç, 2012). Various sub-categories have been identified with teacher candidates on the superior side of self, peer and teacher evaluation, respectively and on the limited side via using qualitative data (Şahin \& Şahin Kalyoncu, 2018).

In a study conducted with physical education teachers, they showed a low rate of frequency in self-assessment and peer review techniques, but a very high frequency in terms of caring level (Asma, Çamliyer, Soytürk, Balcı, \& Çamliyer, 2018). Such a result shows that physical education teachers consider these two alternative evaluations techniques as important, but that they do not use these in a parallel way. During undergraduate education, support should be provided to meet this need by doing and experiencing. In a study in which forearm passing, overhand serve and spike, which are among the technical skills of volleyball, were taught by expert peers, it was conducted with the evaluation data of volleyball coaches through observation forms (Mirzeoğlu, Munusturlar, \& Çelen, 2018). In order to determine the effectiveness of the command and guided discovery methods used in the teaching of basic volleyball techniques to physical education pre-service teachers, evaluation was made through observation forms (Sunay, Gündüz, \& Dolaşır, 2003). In younger age groups, important studies have been carried out in the teaching of technical skills in volleyball (Ghorbanzadeh Koshki, 2013; Yarımkaya, 2013). The teaching of movement analysis and basic technical skills specific to these and other sports branches during the candidacy period of teachers will serve to increase their professional qualifications. By giving particular importance to raising the professional qualifications of teacher candidates, to assessment and evaluation, and to teacher candidates' learning to analyze any basic skill, the aim of this study to analyze efficiency of teacher candidates in movement analysis, self-evaluation and peer evaluation for four basic volleyball skills (forearm passing, setting, underhand serve and overhand serve).

\section{Method}

\subsection{Participants}

The participants were determined by the convenience sampling technique. The participants were 68 teacher 
candidates, 27 of whom were female (39.7\%) and 41 of whom were male (60.3\%). The mean age of the females was $19.22 \pm 1.05$, the mean age of the males was $20.07 \pm 1.48$ and the mean age of all the participants was $19.73 \pm 1.38$. The participants were physical education teacher candidates who had compulsory volleyball courses in three different classes. However, the study consisted of volunteer students in each class.

\subsection{Measurement Tools}

Four observation forms were used in this study. The observation forms developed by Ghorbanzadeh Koshki (2013) were used as tools for evaluating overhand serve and forearm passing skills. Observation forms formed by the researcher and experts were used in the evaluation of the underhand serve and setting skills. In addition, gender and age information of the teacher candidates was recorded.

\subsubsection{Underhand Serve}

Before forming the observation form for the underhand serve skill, an extensive literature review was made (Tiryaki, 1999; Çelenk, 2009; Kabasakal \& Şahan, 2009; FIVB, 2011; Larkin et al., 2012; Çelik, 2014; Dearing, 2019) and expert opinions were obtained. Also, steps were created through watching videos on the internet, and important points in those steps were taken into consideration as observation sub-items. The observation forms were then presented to the experts. This study has the type of the steps of overhand serve and forearm passing skills, and the form was considered in terms of internal consistency and easy use by participants. The experts, who are instructors of university volleyball lessons, carried out the analysis, and only the items which were considered as appropriate by every expert in consensus were included in the observation form. The trial applications of the form were carried out through video analysis with the volleyball players who had played volleyball for at least five years (sports age $=6,87 \pm 2,217$ ), and five of whom were athletes in the league. For the test of self and peer evaluation skill of this group, the interclass correlation coefficient (ICC), which was done with two-way random effects for finding scoring reliability value between students, was found to be .723 . Hereunder, it was seen that scoring reliability of this group was found to be average and acceptable, and the final version of the form was prepared in order to proceed with the study. For physical education teacher candidates, learning to evaluate the movement of this skill is thought to be important as a vocational skill. It is the starting serve which is used in mini-volleyball. The form consists of 15 items. The analysis phases of the underhand serve consist of three parts. These are the pre-shot phase, meeting with the ball and serving at the target. The structure of scoring is between 0 and 4; 0 states that "the behavior has not been observed", whereas 4 states that the phases of the behavior have been applied "at a very good level". The highest score to be obtained is 60 . The Cronbach alpha value of the results of self-evaluation of the participants for the observation form for underhand serve was found to be .904 , and the Cronbach alpha value for peer observation was found to be .896 .

\subsubsection{Setting}

In the formation of the form for the overhand pass skill, a large literature survey was conducted as in the observation form for the underhand serve (Tiryaki, 1999; Çelenk, 2009; Kabasakal \& Şahan, 2009; FIVB, 2011; Larkin et al., 2012; Steel, 2014; Dearing, 2019) and expert opinions were consulted. Also, steps were created through watching videos captured during matches on the internet, and important points in those steps were taken into consideration as observation sub-items. The evaluation of setting was carried out by the experts who evaluated underhand serve, and only those items which were agreed on and approved by the three experts were included in the form. Care was taken to ensure that the structure and visibility of the form were compatible with the other observation forms. It consists of 14 items. The stages of analysis of the setting move consist of three parts; the preparation phase, the application phase and the finishing phase. The structure of scoring is between 0 and 4; 0 states that "the behavior has not been observed", while 4 states that the phases of the behavior have been applied "at a very good level". The highest score to be obtained is 56 . The ICC reliability for scoring among students which was carried out with 16 students was found to be .866 . According to this, the scoring reliability of the items in this group was found to be high and acceptable and so the form was finalized and the main study was started. The Cronbach alpha value for self-evaluation was found to be .891 and the peer evaluation Cronbach alpha value was .938 in the setting observation form.

\subsubsection{Overhand Serve}

The behavioral ladder consisting of 14 items developed by Ghorbanzadeh Koshki (2013) was included. It consists of four parts; throwing the volleyball ball to the desired height, the area for the ball to be hit, the position of the stroke arm and serving at the target. For both forms, the validity coefficient (Content Validity Index) obtained as a result of the content validity carried out by the experts was found to be 0.94 . The highest score to be obtained from the scale is 56 (Ghorbanzadeh Koshki, 2013). In this study, the ICC value of the group participating in the scoring reliability study was .771 . 


\subsubsection{Forearm Pass}

The observation form consisting of 16 items was developed by Ghorbanzadeh Koshki (2013). The highest score to be obtained from the scale is 64 points. It consists of three parts; the preparatory phase, application phase and finishing phase. For both forms, the validity coefficient (Content Validity Index) obtained as a result of the content validity carried out by the experts were found to be 0.94 (Ghorbanzadeh Koshki, 2013). In this study, the ICC value of the group participating in the scoring reliability study was .765 .

\subsection{Procedure}

Measurements were made at each class's Volleyball I course lesson time. The applications were carried out on two different days in successive course hours. Candidate teachers were prepared for the applications with a proper warm-up on both measurement days. Forearm passing and underhand serve applications were made on the first day, video footage was taken and self-evaluation and peer evaluation were done. In the second week, setting and overhand serve applications were made on the second day, video footage was taken and self-evaluation and peer evaluation were done. The basic idea in separating their movements on two different days as two different moves is that the service shots have different mechanical structures. Both service shots were made with at least three balls and repetition in the parallel direction (usually in areas 4 and 5) and in the cross direction (usually in areas 2 and 1). In these two service types, as the discharging and stroking the ball phases must be different from each other, one form of movement done by candidate teachers may affect another. Forearm pass and setting were realized during the game facing one another and was done by passing to each other. In all moves, video shootings were made by the classmates of the participants from the same point and from the side of the bodies. Also, during the shooting, the whole process was recorded by means of a camera to take measures in the event of a setback. It was generally sufficient for the participants to act with a proper motion by making passes facing each other in three minutes. In case of agitation or an unsuitable pass, the time was extended. All candidates made analysis of his/her and his/her friend's moves which was determined according to the order of the list. At that stage, the peers were not aware of each other and were kept away from each other. Two participants only evaluated themselves because of carelessness or for other reasons, since voluntarism and an ethical approach were prioritized, and so re-evaluation was not insisted upon and their data were excluded from evaluation. In the motion analysis footages, the most appropriate motion was evaluated in slow motion three times.

\subsection{Data Analysis}

In the analysis of the data, basic descriptive statistics such as mean and standard deviation were used. In the comparison of the groups, $t$ test was used and Pearson correlation and partial correlation tests were used for the correlation analysis. Interclass correlation coefficient (ICC) and Cronbach alpha analyses were used for reliability analysis. Type 1 error was accepted as $5 \%$.

\subsection{Research Model}

In the study, the observation technique was used by video recording. Physical education teacher candidates analyzed the skills of their own practice and a friend's practice for each basic technique and an observation form was prepared for this purpose. The study is based on the structured observation technique. In this technique, a better structuring and systematic approach to observation is used, there is a coding system and it is easier to attain reliability and validity in gathering information (Büyüköztürk, Kılıç Çakmak, Akgün, Karadeniz, \& Funda, 2012).

\section{Results}

Table 1. The correlation between self-evaluation and peer assessment in teacher candidates' basic volleyball skills

\begin{tabular}{|c|c|c|c|c|}
\hline \multirow{2}{*}{$\begin{array}{c}\text { Basic Volleyball Skills } \\
\text { Self-evaluation } \\
\end{array}$} & \multicolumn{4}{|c|}{ Peer Evaluation } \\
\hline & Underhand serve & Overhand serve & Forearm pass & Setting \\
\hline Underhand serve & $.338^{* *}$ & & & \\
\hline Overhand serve & & $.499^{* *}$ & & \\
\hline Forearm pass & & & $.601^{* *}$ & \\
\hline Setting & & & & $.613^{* *}$ \\
\hline
\end{tabular}

As a result of the Pearson correlation analysis made to determine whether there was a significant correlation between self-evaluation and peer evaluation scores, it was found that there was a positive significant correlation between them. This correlation is for underhand serve $(\mathrm{r}=.338 ; \mathrm{p}=.005)$, for overhand serve $(\mathrm{r}=.499 ; \mathrm{p}=.000)$, for 
forearm pass $(\mathrm{r}=.601 ; \mathrm{p}=.000)$ and for setting $(\mathrm{r}=.613 ; \mathrm{p}=.000)$.

Table 2. The correlation between self-evaluation and peer evaluation in the basic volleyball skills of the teacher candidates when the age and gender variables are examined together

\begin{tabular}{|c|c|c|c|c|c|}
\hline \multirow{2}{*}{$\begin{array}{l}\text { Basic Volleyball Skills } \\
\text { Self-evaluation }\end{array}$} & \multirow[t]{2}{*}{ Self-evaluation } & \multicolumn{4}{|c|}{ Peer evaluation } \\
\hline & & Underhand serve & Overhand serve & Forearm pass & Setting \\
\hline \multirow[t]{4}{*}{ Age \& Gender } & Underhand serve & .337 & & & \\
\hline & Overhand serve & & .501 & & \\
\hline & Forearm pass & & & .606 & \\
\hline & Setting & & & & .615 \\
\hline
\end{tabular}

According to the results of the partial correlation analysis which was done in order to determine if there was a significant correlation between scores for self-evaluation and peer evaluation by examining the age and gender variables together, it was found that there was a positive significant correlation between them. This correlation is for underhand serve $(\mathrm{r}=.337 ; \mathrm{p}=.006)$, for overhand serve $(\mathrm{r}=.501 ; \mathrm{p}=.000)$, for forearm pass $(\mathrm{r}=.606 ; \mathrm{p}=.000)$, and for setting $(\mathrm{r}=.615 ; \mathrm{p}=.000)$. These findings seem to increase the Pearson correlation test results negligibly.

Table 3. Comparison of students' self-evaluation and peer evaluation in basic volleyball skills of teacher candidates

\begin{tabular}{llllllll}
\hline Basic Volleyball Skills & Group & $\mathrm{n}$ & $\mathrm{X}$ & $\mathrm{Sd}$ & $\mathrm{df}$ & $\mathrm{t}$ & $\mathrm{p}$ \\
\hline Underhand serve & Self-evaluation & 68 & 49.60 & 7.755 & 134 & 1.007 & .316 \\
& Peer evaluation & 68 & 48.25 & 7.914 & & & \\
Overhand serve & Self-evaluation & 68 & 45.42 & 8.255 & 134 & .094 & .925 \\
& Peer evaluation & 68 & 45.29 & 8.160 & & & \\
Forearm Pass & Self-evaluation & 68 & 54.52 & 7.935 & 134 & .712 & .478 \\
& Peer evaluation & 68 & 53.51 & 8.670 & & & \\
Setting & Self-evaluation & 68 & 47.14 & 6.913 & 134 & 1.320 & .189 \\
& Peer evaluation & 68 & 45.30 & 9.167 & & & \\
\hline
\end{tabular}

As a result of the t-test which was used to determine whether there was a significant difference between the self-evaluation and peer evaluation scores of the teacher candidates, it was found that there was no significant difference between them ( $p>05)$. Therefore, the teacher candidates observed the moves in a similar manner while he/she evaluated himself/herself and his/her peer evaluated his/her moves.

\section{Discussion}

As a result of this study, which was conducted in order to examine the self-evaluation and peer evaluation competencies of physical education teacher candidates' four basic volleyball skills, it was found that they had the similar quality of evaluation. The results show that the correlation between self and peer evaluation is generally moderate (Büyüköztürk, 2002). When the effect of the age and sex variables was examined, no significant difference was found in correlation according to the Pearson correlation analysis results. Based on this, it can be concluded that the teacher candidates did not fall under the influence of these two independent variables, which differ in the application of the process. In addition to this, the difference analysis also supported the idea that both evaluations were not performed differently. It is very important to be honest to oneself and his/her peers in order to achieve an objective evaluation. This indicates that the process is healthy. The study conducted by Mirzeoğlu, Munusturlar and Çelen (2014), which used a peer teaching model and observation form as evaluation tools and at the same time included academic learning time, is among the important studies on this subject. In this study conducted with students of the High School of Physical Education and Sports, no difference was found between the scores of the peer teaching group and the other group, in terms of forearm pass, overhand serve and spike skill achievement test scores, and the experienced teaching group was found to have a higher percentage of academic learning time than the novice teaching group (Mirzeoglu et al., 2018). In an extensive study in which there was a comparison between basic skills taught in volleyball lessons for physical education teacher candidates and the method of command and discovery method in a period of one semester, a movement analysis was made in the form of expert evaluation and it was found that both teaching methods were effective (Yarımkaya, 2013). In a study which investigated the effect of three different feedbacks on learning service and forearm passing skills in secondary school students, observation forms including move analysis were used and verbal + visual feedback 
provided by the teacher was found to contribute positively to student success (Ghorbanzadeh Koshki, 2013). As a result of the serving practices done by bringing self-confidence to the forefront, which is one of the affective field outputs, it was determined that this increased (Yarımkaya, 2013).

Many studies in which alternative assessment and evaluation are prioritized and self-peer-expert evaluation has been used have been included in the literature. Some of these were carried out with teacher candidates (Göçer, 2016; Gömleksiz \& Koç, 2012; Kavanoz \& Yüksel, 2010; Kösterelioğlu \& Çelen, 2016; Mirzeoğlu et al., 2018; Sunay et al., 2003; Şahin \& Şahin Kalyoncu, 2018; Yılmaz, 2017; Yurdabakan, 2012), while some of them were carried out with children and adolescents (Ghorbanzadeh Koshki, 2013; Yarımkaya, 2013), and their results are consistent with the results of this study. Whether it is used in teacher candidates or in children and adolescents, in both cases, the effectiveness of education and training in increasing efficiency has emerged. The observation technique used in the research is both the oldest and the most modern one of the data collection techniques, and besides its various advantages, it has the disadvantage that the observer and the recorder of the data can be biased (Çömlekçi, 2001). In this study and many other studies presented above, the aim is to reduce bias by using different evaluation structures and different evaluators to prevent this. Physical education teachers attached importance to self and peer evaluation techniques but they were found to have low frequency in using them (Asma et al., 2018). This may be caused by the fact that they do not have the chance to try what they have learnt as the content during their assessment and evaluation lessons in terms of field-specific practical transfer. In addition, the development of communication skills is thought to be important among the other important outputs of sports environments (Tepeköylü, Soytürk, \& Çamliyer, 2009). Techniques such as self and peer evaluation can strengthen mutual communication and interaction; in addition to this, perhaps the support of self-efficacy beliefs in teaching department students can be increased (Yanık, 2017).

The results obtained in this study show that physical education teacher candidates' self-evaluation and peer evaluation competencies show similarities, and they also show that age and gender do not affect the motion analysis. The final conclusion has been made that doing self and peer evaluation is important in terms of increasing their learning abilities and being reflective when they start their working life.

\section{Suggestions}

Studies that involve alternative measurement, modern teaching approaches and technical analysis specific to different sports branches using motion analysis can be effective in increasing physical education teacher candidates' preparation for the profession. Findings of teacher candidates' use of alternative evaluation techniques such as self and peer evaluation in their internship applications, such as the teaching practice application, can make a significant contribution to the literature.

\section{References}

Asma, M., Çamlıyer, H., Soytürk, M., Balcı, T., \& Çamlıyer, H. (2018). An investigation on alternative measurement and evaluation in physical education and sport teaching. Sakarya University Journal of Education, 8(3), 37-62. https://doi.org/10.19126/suje.398201

Büyüköztürk, Ş. (2002). Sosyal bilimler için veri analizi el kitabı (2. Basım). Ankara: Pegem A Yayıncılık.

Büyüköztürk, Ş., Kılıç, Ç. E., Akgün, Ö. E., Karadeniz, Ş., \& Funda, D. (2012). Bilimsel araştırma yöntemleri (12. Bask1). Ankara: Pegem Akademi.

Çelenk, B. (2009). Voleybol temel eğitimi. Ankara: Spor Yayınevi ve Kitapevi.

Çelik, A. (2014). Mini voleybol ögreniyorum. Ankara: Spor Yayınevi ve Kitapevi.

Çelikten, M., Şanal, M., \& Yeni, Y. (2005). Teaching profession and features. Journal of Social Sciences Institute, 19(2), 207-237.

Çömlekçi, N. (2001). Bilimsel araştırma yöntemi ve istatistiksel anlamlılık sınamaları (1. Basım). Ankara: Bilim Teknik Yayınevi.

Dearing, J. (2019). Volleyball fundamentals (2nd Edi). Human Kinetics, Inc. https://doi.org/10.1098/rstb.2000.0775

Federation Internationale de Volleyball. (2011). Teaching basic individual techniques. In Coaches manual 2011 (pp. 69-118). Federation Internationale de Volleyball. Retrieved from https://volleyvekst.files.wordpress.com/2017/04/fivb_coach.pdf

Ghorbanzadeh Koshki, B. (2013). Voleybolda servis ve manşet becerilerinin öğretiminde geribildirimin etkisi. Master thesis, Health Sciences Institute, Ankara University. Retrieved from 
https://tez.yok.gov.tr/UlusalTezMerkezi/tezSorguSonucYeni.jsp

Göçer, A. (2016). The evaluation of pre-service Turkish student teachers' micro-teaching applications in their own views. Erciyes University Journal of the Institute of Social Sciences, XI(I), 21-39. Retrieved from http://dergipark.gov.tr/download/article-file/218450

Gömleksiz, M. N., \& Koç, A. (2012). Peer assessment in teaching computer usage. E-Journal of New World Sciences Academy, 7(1). Retrieved from http://ijrte.eab.org.tr/1/spc.issue/1s.hatipoglu.pdf

Güler, N. (2015). Ĕgitimde ölçme ve değerlendirme (8. Bask1). Ankara: Pegem Akademi.

Kabasakal, K., \& Şahan, H. (2009). Voleybol ögretim yöntemleri (S. Akpınar, Ed.). Karaman: Şelale Ofset Matbaası.

Kasap, H., Kemertaş, İ., \& Sibel, N. (2018). Eğitimde ve spor eğitiminde ölçme ve değerlendirme (1. Basım). Ankara: Nobel.

Kavanoz, S., \& Yüksel, G. (2010). An investigation of peer-teaching technique in student teacher development. The International Journal of Research in Teacher Education, 1(3), 10-19. Retrieved from http://ijrte.eab.org.tr/1/spc.issue/1s.hatipoglu.pdf

Kösterelioğlu, İ., \& Çelen, Ü. (2016). Evaluation of the effectiveness of self-assessment method. Elementary Education Online, 15(2), 671-681. https://doi.org/10.17051/io.2016.44304

Larkin, T. E., Defrantz, A. L., Bryson, J. E., Burke, Y. B., Chang, J. M., Easton, J. L., ... Vasquez, G. R. (2012). Teaching volleyball technique: basic skills. In E. Roque \& J. Hansen (Eds.), LA84 Foundation Volleyball Coaching Manual (pp. 111-115; 124). Los Angeles.

Mirzeoğlu, A. D., Munusturlar, S., \& Çelen, A. (2018). The effects of peer teaching model on academic learning time and learning volleyball skills. Hacettepe University Journal of Sport Sciences, 25(4), 184-202. https://doi.org/10.17644/sbd.171672

Mosston, M., \& Ashworth, S. (2008). Teaching physical education. Spectrum institute for teaching and learning (First Onli). https://doi.org/10.17226/18314

Şahin, M. G., \& Şahin, K. D. (2018). Investigation of preservice teachers' opinions about self-, peer- and teacher assessment. Kastamonu University Kastamonu Education Journal, 26(4), 1-9. https://doi.org/10.24106/kefdergi.393278

Sayın, M. (2011). Hareket ve beceri öğrenimi (M. Altun Ed.). Ankara: Spor Yayınevi ve Kitapevi.

Schmidt, R. A., \& Wrisberg, C. A. (2000). Motor learning and performance. Human Kinetics, Inc.

Sezgin, F., Kavgaci, H., \& Kilinc, A. C. (2011). Self-evaluations of educational administration and supervision graduate students in Turkey. Journal of Higher Education and Science, 1(3), 161. https://doi.org/10.5961/jhes.2011.024

Sunay, H., Gündüz, N., \& Dolaşir, S. (2003). The effects of different teaching methods used in teaching basic volleyball techniques on physical education candidates. Gazi Journal of Physical Education and Sport Sciences, VIII(3), 19-24. Retrieved from http://dergipark.gov.tr/download/article-file/292339

Tepeköylü, Ö., Soytürk, M., \& Çamlıyer, H. (2009). Examining the levels of perception of communication skills in physical education and sports college (PESC) students in terms of pre-determined variables. SPORMETRE Journal of Physical Education and Sport Sciences, VII(3), 115-124.

Tiryaki, S. E. (1999). Yeni başlayanlar için voleybol. Ankara: Spor Kitapevi.

Topping, K. J., Smith, E. F., Swanson, I., \& Elliot, A. (2000). Formative peer assessment of academic writing between postgraduate students. Assessment and Evaluation in Higher Education, 25(2), 149-169. https://doi.org/10.1080/713611428

Turkish Language Institution. (2019). Current Turkish Dictionary. Retrieved from http://www.tdk.gov.tr/index.php?option=com_gts\&arama=gts\&guid=TDK.GTS.5c5ee8e8902d76.0500585 7

Yanık, M. (2017). The beliefs of self-sufficiency of candidate teachers of physical education and sport. Atatürk University Journal of Sport Sciences, 19(4), 148-161.

Yarımkaya, E. (2013). 12-14 yaş arasi ilkögretim öğrencilerinin özgüven düzeylerinin voleybolda servis atma becerisi üzerine etkisi. Selçuk Üniversitesi, Sağlık Bilimleri Enstitüsü. 
Yaşar, M. (2014a). Ölçme ve değerlendirme ile ilgili temel kavramlar. In S. Tekindal (Ed.), Eğitimde Ölçme ve Değerlendirme (p. 29). Pegem Akademi.

Yaşar, M. (2014b). Ölçme ve Değerlendirmenin Önemi. In S. Tekindal (Ed.), Eğitimde Ölçme ve Değerlendirme (4. Basım, p. 4). Ankara.

Y1lmaz, S. (2017). Preservice mathematics teachers' self-report levels on spatial ability. Journal, International Trends, New Education (Science), 6(1), 10-17.

Yurdabakan, İ. (2011). The view of constructivist theory on assessment: alternative assessment methods in education. Journal of Faculty of Educational Sciences, 44(1), 51-77. https://doi.org/10.1007/978-90-481-8799-7

Yurdabakan, İ. (2012). The effect of co- and peer assessment training on self-assessment skills of teacher trainees. Education and Science, 37(163), 190-202.

\section{Copyrights}

Copyright for this article is retained by the author, with first publication rights granted to the journal.

This is an open-access article distributed under the terms and conditions of the Creative Commons Attribution license (http://creativecommons.org/licenses/by/4.0/). 